\title{
THE IMPACT OF THE ECHR AND THE CASE LAW OF THE ECtHR ON CIVIL PROCEDURE IN UKRAINE
}

\author{
Vyacheslav Komarov and Tetiana Tsuvina
}

Summary: 1. Introduction. - 2. The Harmonization of National Legislation with ECHR Requirements as a Desideratum for Civil Justice Reforms in Ukraine. - 3. The Rule of Law as a Principle of Civil Procedure and the Application of the Case Law of the ECtHR . - 4. Right to a Fair Trial: the Ukrainian Context. - 5. Pilot Judgments of the ECtHR and Civil Procedure Practice. - 6. The Review of a Case on Exceptional Circumstances after the Judgment of the ECtHR. - 7. Conclusions.

To cite this article: V Komarov, $T$ Tsuvina 'The Impact of the ECHR and the Case law of the ECtHR on Civil Procedure in Ukraine' 2021 1(9) Access to Justice in Eastern Europe 79-101. D0l: 10.33327/AJEE-18-4.1-a000047

To link to this article: https://doi.org/10.33327/AJEE-18-4.1-a000047

Submitted on 01 Dec 2020 / Revised 30 Jan 2021 / Approved 22 Feb 2021 / Published online: 01 Mar 2021 View data Submit your article to Access to Justice in Eastern Europe http://ajee-journal.com/submissions

\section{ACKOWLEDGMENTS}

Authors would like to express their gratitude to the reviewers of the article for their remarks and recommendations which allowed improvements to the article.

\section{CONFLICTS OF INTEREST}

Co-authors declare no conflict of interest of relevance to this topic.

\section{CONTRIBUTORS}

Both the co-authors contributed equally to the intellectual discussion underlying this paper, literature exploration, writing, data collection and analysis, interpretation, review and editing, and accept responsibility for the content of the paper.

Prof. Vyacheslav Komarov is a Member of the National Academy of Legal Sciences of Ukraine, Vice-Rector for Academic and Methodological Work, Yaroslav Mudryi National Law University. https://orcid.org/0000-0002-5351-1475

Dr. Tetiana Tsuvina serves as an Associate Professor of Civil Procedure Department, Yaroslav Mudryi National Law University. https://orcid.org/0000-0002-5351-1475 


\title{
THE IMPACT OF THE ECHR AND THE CASE LAW OF THE ECTHR ON CIVIL PROCEDURE IN UKRAINE
}

\author{
Komarov Vyacheslav \\ Professor, Member of the National Academy \\ of Legal Sciences of Ukraine, \\ Yaroslav Mudryi National Law University, Ukraine \\ Tsuvina Tetiana \\ PhD (Law), Associate Professor of \\ Civil Procedure Department, \\ Yaroslav Mudryi National Law University, Ukraine
}

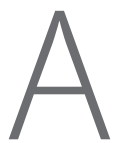

bstract The article addresses the impact of the ECHR and the case law of the ECtHR on civil procedure in Ukraine. In the context of the provisions of national legislation and judicial practice, the authors analyse the areas of the harmonization of national legislation with the requirements of the ECHR and the practice of the ECtHR in light of the 2016 constitutional reform of justice and the new edition of the Civil Procedure Code of Ukraine. Special attention is paid to the embodiment of the rule of law principle during a trial in civil cases and the implementation of international standards of the right to a fair trial (para. 1 Art. 6 of the ECHR). From the point of view of institutional interaction between the ECtHR and national courts, the procedures of pilot judgments, the review of the case in exceptional circumstances was analysed.

Keywords: Convention for the Protection of Human Rights and Fundamental Freedoms, European Court of Human Rights, right to a fair trial, rule of law, pilot judgment, review of the case in exceptional circumstances, Ukraine.

\section{INTRODUCTION}

The ratification of the Convention for the Protection of Human Rights and Fundamental Freedoms (hereinafter - ECHR) in 1950 was a landmark event for the Council of Europe member states which heralded the conception of a single European space in which a person and a person's rights are recognized as the highest legal value. Since then, we can observe how the ECHR affects the national case law through the national courts' application of the ECtHR judgments. In this regard Michele de Salvia notes that 'since that time a national judge is bound to proclaim law as a human rights judge, and everybody who applies to the court should know that he or she has the right to refer to the ECHR as it is interpreted by the ECtHR.'

The ECHR was ratified by Ukraine in $1997,{ }^{2}$ which paved the way for the harmonization of the national civil procedural legislation and the practice of civil procedure with international

$1 \quad$ M de Salvia, Precedents of the European Court of Human Rights. Guidelines for case law relating to the European Convention for the Protection of Human Rights and Fundamental Freedoms. Judicial practice from 1960 to 2002 (Yuridicheskiy tsentr Press 2004) 21.

The Law of Ukraine 'On Ratification of the Convention for the Protection of Human Rights and Fundamental Freedoms of 1950, the First Protocol and Protocols No 2, 4, 7 and 11 to the Convention' No 475-97-BP [1997] Vidomosti of the Verkhovna Rada 40/263 <https://zakon.rada.gov.ua/laws/ show/475/97-вp/card2\#Card> accessed 01 December 2020. 
standards. The ECHR and the practice of the ECtHR are recognized as sources of law in Ukraine (para. 1 Art. 17 of the Law of Ukraine 'On Enforcement of Decisions and Application of the Case Law of the European Court of Human Rights. ${ }^{3}$ Under the Civil Procedure Code of Ukraine (hereinafter - CPC) international treaties to which the parliament consented shall be recognized as sources of civil procedural law (para. 1 Art. 3 of the CPC), and if such international treaties provide other provisions than that which are established in the $\mathrm{CPC}$, provisions of international treaty shall apply (para. 2 Art. 3 of the CPC). Besides this, para. 4 Art. 10 of the CPC also recognizes the ECHR and the practice of the ECtHR as sources of law and prescribes judges to apply them during the trial and when delivering a judgment.

Notwithstanding the above-mentioned provisions of civil procedure legislation, ECtHR statistics point to a systemic problem connected with the non-enforcement of international obligations at the human rights protection area which were undertaken by Ukraine according to the ECHR. Thus, in 2019 Ukraine took the third place (after the Russian Federation and Turkey) in the number of applications submitted to the ECtHR which added up to $14.8 \%$ of the total number of applications submitted to the ECtHR and was ranked in third place after the abovementioned countries by the number of judgments against it (109 judgments, accounting for $12.33 \%$ of all judgments delivered in 2019). ${ }^{4}$ As of 31 October 2020, 10,100 applications were filed against Ukraine which accounted for $16.5 \%$ of all the applications submitted to the ECtHR. ${ }^{5}$

Among the judgments delivered against Ukraine in 2019, $24.76 \%$ were connected with a violation of para. 1 Art. 6 of the ECHR, in particular with the right to a fair hearing or reasonable time for a trial and the execution of court decisions. ${ }^{6}$ During the entire period of the ECtHR's existence (as of 2020), 96,791 complaints were filed against Ukraine. ${ }^{7}$ Particularly significant in this context is the situation with the problem of the non-enforcement of the decisions of Ukrainian courts where the debtor is the state, which was recognized by the ECtHR in 2009 in the case Yuriy Nikolaevich Ivanov v. Ukraine, ${ }^{8}$ and subsequently reiterated in the case of Burmych v. Ukraine, ${ }^{9}$ where the ECtHR brought together more than 12,000 complaints in one proceeding. In this regard, there is an urgent need to bring both civil procedural legislation and the practice of civil justice in line with international standards of civil procedure in order for Ukraine to fulfill its international obligations in the area of human rights.

\section{THE HARMONIZATION OF NATIONAL LEGISLATION WITH ECHR REQUIREMENTS AS A DESIDERATUM FOR CIVIL JUSTICE REFORMS IN UKRAINE}

The ratification of the ECHR obliges the state to bring its legislation in line with European human rights standards. In this context, the ECtHR notes that 'the domestic law must itself be

3 The Law of Ukraine 'On Enforcement of Decisions and Application of the Case Law of the European Court of Human Rights' No 3477-IV [2006] Vidomosti of the Verkhovna Rada 30/260 < https://zakon. rada.gov.ua/laws/show/3477-15/card2\#Card> accessed 01 December 2020.

4 European Court on Human Rights, 'The ECHR in Facts and Figures 2019' (2020). < https://www.echr. coe.int/Documents/Facts_Figures_2019_ENG.pdf> accessed 01 December 2020.

5 European Court on Human Rights, 'Pending applications allocated to a judicial formation, 31 October 2020'. $<$ https://www.echr.coe.int/Documents/Stats_pending_month_2020_BIL.PDF> accessed 01 December 2020 .

6 European Court on Human Rights (n 4).

7 European Court on Human Rights, 'Overview 1959-2019 ECHR' (2020), p 5. < https://www.echr.coe. int/Documents/Overview_19592019_ENG.pdf > accessed 01 December 2020.

$8 \quad$ Yuriy Nikolaevich Ivanov v Ukraine App No 40450/04 (ECtHR 15 October 2009).

9 Burmych $v$ Ukraine App No 46852/13 (GC ECtHR 12 October 2017). 
in conformity with the ECHR, including the general principles expressed or implied therein. ${ }^{10}$ Taking into account this approach, constitutional reform, which was initiated with the adoption of the Law of Ukraine 'On Amendments to the Constitution of Ukraine (Regarding Justice)' No. 1401-VIII adopted on 2 June 2016, ${ }^{11}$ was held under the slogan of Europeanization of the Ukrainian civil procedure and its approximation to the best European models. In this regard the provisions of the ECHR and the practice of the ECtHR play a key role.

First of all, constitutional reform laid the grounds for changes both in the judicial system of Ukraine and in the administrating of justice in civil cases. The most significant innovation of the Law of Ukraine 'On Amendments to the Constitution of Ukraine (Regarding Justice)' in terms of the judiciary was the liquidation of higher specialized courts and the Supreme Court of Ukraine and the introduction of a new Supreme Court as the highest judicial body in the country.

Before the amendments, the judicial system in Ukraine consisted of local, appellate courts, the highest specialized courts (the High Specialized Court of Ukraine for Civil and Criminal Cases, the Highest Economic Court of Ukraine and the Highest Administrative Court of Ukraine) and the Supreme Court of Ukraine. This system of judiciary has been repeatedly criticized by the Venice Commission for Democracy through Law, mainly because the Supreme Court of Ukraine did not in fact function as a cassation court, but instead was confined to reviewing the highest courts' judgments on the grounds of a lack of cassation case law unity. ${ }^{12}$

As a result of the constitutional reform, the highest specialized courts and the Supreme Court of Ukraine were liquidated, and the new Supreme Court was established. According to current legislation, the Supreme Court performs the function of a cassation instance and is responsible for ensuring the unity of judicial practice. There are four courts of cassation in the structure of the Supreme Court, particularly the Administrative Cassation Court, the Commercial Cassation Court, the Criminal Cassation Court, the Civil Cassation Court and the Grand Chamber of the Supreme Court. This restructuring of the judiciary was applauded by international experts, ${ }^{13}$ since it resulted in the Supreme Court regaining the cassation function and not only a nominal but also a real recognition of its status as the highest judicial body.

One of the prominent changes is a new set of rules for judicial jurisdiction (para. 3 Art. 124 of the Constitution of Ukraine). The previous provision, according to which the jurisdiction of the courts extended to all legal relations arising in the state, effectively set a model of full or unlimited judicial jurisdiction. Currently, the law contains a provision that judicial jurisdiction extends to any legal dispute and criminal charge, and in cases provided by law,

$10 \quad$ Winterwerp $v$ Netherlands (App No 6301/73) ECHR 24 October 1997, para 45.

11 The Law of Ukraine 'On Amendments to the Constitution of Ukraine (Regarding Justice)' No 1401VIII [2016] Vidomosti of the Verkhovna Rada 28/532 < https://zakon.rada.gov.ua/laws/show/140119\#Text> accessed 01 December 2020.

12 Venice Commission and the Directorate of Co-operation within the Directorate General of Human Rights and Legal Affairs of the Council of Europe, 'Joint Opinion on the Draft Law "On the Judicial System and the Status of Judges of Ukraine"” (Venice, 12-13 March 2010) < https://www.venice.coe.int/ webforms/documents/?pdf=CDL-AD(2010)003-e > accessed 01 December 2020; Venice Commission and the Directorate of Justice and Human Dignity within the Directorate General of Human Rights and Rule of Law of the Council of Europe, 'Joint opinion on the draft law amending the Law "On the judiciary and the status of judges and other legislative acts of Ukraine"' (Venice, 14-15 October 2011) <https://www.venice.coe.int/webforms/documents/?pdf=CDL-AD(2011)033-e> accessed 01 December 2020.

13 Venice Commission and the Directorate General of Human Rights and Rule of Law (DGI) of the Council of Europe, "Joint Opinion on the draft amendments to the Law "On the Judiciary and the Status of Judges" and certain Laws on the activities of the Supreme Court and Judicial Authorities (Draft Law no. 3711)' (8-9 October 2020) < https://www.venice.coe.int/webforms/documents/?pdf=CDL$\mathrm{AD}(2020) 022$-e $>$ accessed 01 December 2020. 
to other legal relationships. Further restrictions on judicial jurisdiction are allowed if the law establishes a mandatory pre-trial procedure for settling a dispute (para. 4 Art. 124 of the Constitution of Ukraine).

Such changes to the constitutional provisions on jurisdiction were caused by the influence of the provisions of para. 1 Art. 6 of the ECHR, according to which the scope of the right to a fair trial is defined through such concepts as the 'determination of civil rights and obligations' and 'criminal charge', which have autonomous interpretation in the practice of the ECtHR. Thus, the civil limb of Art. 6 of the ECHR can be applied only if 'dispute over civil rights and obligations' exists, which can be established on the basis of criteria such as: a) the existence of a dispute ('contestation') over a right; b) such a right can be said, at least on arguable grounds, to be recognized under domestic law; c) the outcome of the proceedings must be directly decisive for the right in question; d) 'civil' character of the disputable right or obligation. ${ }^{14}$ Trying to bring the general constitutional formula of judicial jurisdiction closer to the provisions of para. 1 Art. 6 of the ECHR, the legislator defined the sphere of judicial jurisdiction through the concept of 'legal dispute' with certain limitations and exceptions. New constitutional provision indicates the transition to a limited model of judicial jurisdiction and emphasizes the immanent function of courts which is resolving legal disputes.

The other important constitutional innovations inspired by the influence of the ECHR include: the changes in the catalogue of principles of justice, the constitutional provisions on professional legal aid held by the bar, limiting the role of prosecutors in civil procedure, restrictions on the right of access to courts in cassation proceedings and the implementation of so called 'filters of cassation appeal' etc.

Such fundamental constitutional changes were further specified in the civil procedure legislation with the adoption of a new edition of the CPC in accordance with the Law of Ukraine 'On Amendments to the Commercial Procedure Code of Ukraine, Civil Procedure Code of Ukraine, Code of Administrative Procedure of Ukraine and other legislative acts' № 2147-VIII on 3 October 2017, which entered into force on 15 December 2017. ${ }^{15}$ Amendments to the CPC actually marked the reform of civil procedure, which generally reflects European trends in terms of the harmonization of national procedural systems to international standards of a fair trial and access to justice. The main consequences of this reform, which indicate the efforts of the national legislator to bring domestic civil procedural law to international standards in this area, include:

- a recognition of the effective protection of violated, unrecognized or disputed rights, freedoms or interests of individuals, the rights and interests of legal entities, and the interests of the state as a goal of civil procedure;

- updating the catalogue of principles of civil procedure and inserting it in the CPC;

- a differentiation of civil procedure at the level of the court of first instance due to the introduction of small claim proceedings as a separate simplified procedure;

- an expansion of a court's powers with regard to managing the course of court proceedings and ordering the disclosure of evidence, and the introduction of elements of judicial case management;

- strengthening the procedural discipline of the parties by introducing at the legislative level a prohibition of procedural rights abuses and providing mechanisms to prevent them;

14 Hamer v France App No 19953/92 (ECtHR, 07 August 1996); Le Compte, Van Leuven and De Meyere $v$ Belgium App No 6878/75 (ECtHR 23 June 1981).

15 The Law of Ukraine 'On Amendments to the Commercial Procedure Code of Ukraine, Civil Procedure Code of Ukraine, Code of Administrative Procedure of Ukraine and other legislative acts' No 2147VIII [2017] Vidomosti of the Verkhovna Rada 48/436 < https://zakon.rada.gov.ua/laws/show/214719\#Text> accessed 01 December 2020. 
- strengthening the consensual principles of civil procedure by introducing a dispute settlement procedure with the participation of a judge, aimed to reach a pre-trial settlement of the dispute between the parties;

- limiting the grounds for the prosecutor's participation in civil proceedings to cases where representation is made in the interests of the state;

- enhancing the role of the bar and legal aid institutions;

- the 'digitalization' of civil procedure;

- strengthening the classic three-instance model of civil procedure with the creation of a new Supreme Court as the single highest court of the state, which functions as a cassation instance and is responsible for ensuring the unity of judicial practice among different types of proceedings (civil, commercial, administrative) through the possibility of conducting cassation proceedings in the joint chambers or the Grand Chamber of the Supreme Court.

It is obvious that the changes in civil procedural law had objective reasons and, despite differing views and discussions on the expected consequences of judicial reform, were a response to existing challenges to improve the efficiency of civil procedure. These changes were caused by the direct influence of the ECHR and the case law of the ECtHR as well as the conclusions and recommendations of the Council of Europe, and generally reflected panEuropean trends in civil procedure. In this sense, we can talk about the direct impact of the ECHR on the reform of civil justice in Ukraine in terms of updating civil procedural law, and the further possibility of building the experience of national courts related to its application.

\section{THE RULE OF LAW AS A PRINCIPLE OF CIVIL PROCEDURE AND THE APPLICATION OF THE CASE LAW OF THE ECtHR}

The principles of civil procedure are considered as one of the most fundamental concepts of civil procedural law on a par with the goal and objectives of civil procedure. From this point of view, the principles are the fundamental grounds of civil justice that set the direction of scientific research and the dimensions of modern civil procedure in democratic societies with their orientation to the respect and protection of human rights and the rule of law. In view of the above, special attention should be paid to the changes related to the catalogue of civil procedural principles at the constitutional level as well as in the CPC, which was obviously designed under the influence of the case law of the ECtHR. These changes determine the administration of justice and directly affect the model of civil procedure and its effectiveness.

The updated catalogue of justice principles, without reference to its type (civil, commercial, administrative or criminal), is contained in Art. 129 of the Constitution of Ukraine, according to which a judge, who administers justice, is independent and guided by the rule of law. The main principles of justice are: 1) the equality of all participants of the trial before the law and the court; 2) the assuring proof of guilt; 3 ) the adversarial principle and freedom of the parties in presenting evidence to the court and proving their persuasiveness before the court; 4) supporting criminal charges in court by the prosecutor; 5) providing the accused with the right to defence; 6) publicity of the trial and its complete fixation by technical tools; 7) the trial taking place within a reasonable time; 8) ensuring the right to an appellate review of the case - and in cases specified by law - to a cassation appeal of a court decision; 9) the binding nature of the court decision. The law may also determine other principles of justice. According to Art. $129^{1}$ of the Constitution of Ukraine, the court delivers decisions on behalf of Ukraine. The court decision is binding. The state ensures the execution of a court decision in the manner prescribed by law. The court exercises control over the execution of the court decision. 
These constitutional provisions are detailed in civil procedural law. Thus, in accordance with para. 3 of Art. 2 of the CPC, last amended in 2017, the main principles of civil procedure are: 1) the rule of law; 2 ) respect for honour and dignity, the equality of all participants of the trial before the law and the court; 3 ) publicity and openness of the trial and its complete fixation by technical tools; 4) the adversarial principle; 5) disposition; 6) proportionality; 7) the binding nature of the court decision; 8) ensuring the right to an appellate review of the case; 9) ensuring the right to a cassation review in cases established by law; 10) reasonable time for a trial; 11) a prohibition of procedural rights abuse; 12) the reimbursement of court fees to the party in whose favour the court decision was delivered.

A fundamental issue in the context of legal technique and procedural law-making is the implementation of the rule of law in the national legal system. In foreign literature it is common to distinguish between formal and substantive conceptions of the rule of law. ${ }^{16}$ Formal concepts usually make a 'distinction between law and justice, ${ }^{17}$ and therefore exclude any evaluation of the content of legal norms and focus primarily on the law adopting procedure, their structure, the requirements for the text of legislative provisions, requiring that the latter should be general, clear, non-retrospective, sustainable, and so on. Instead, substantive conceptions of the rule of law involve substantive requirements for the legislative provisions. From this perspective, the rule of law also demands guarantees of individual and political human rights and freedoms, a compliance with general principles of law, moral requirements, substantive justice, considerations of general welfare and elements of political morality, etc. At the same time, it is noted in the literature that formal conceptions of the rule of law originate from legal positivism and deal, so to speak, with 'law as it is', while substantive conceptions based on natural law thinking focus on 'law as it should be. ${ }^{18}$

Though the principle of the rule of law is enshrined in Art. 8 of the Constitution of Ukraine, in doctrine its interpretation was often reduced to the requirements of formal legality, which is incompatible with the modern understanding of the rule of law. Recently, however, some positive developments in this regard have been noted. Thus, the interpretation of the rule of law given by the European Commission for Democracy through Law (Venice Commission) is recognized as an authoritative interpretation of rule of law in Ukraine. According to its report, the key elements of the rule of law are: 1) legality, including a transparent, accountable and democratic process for the enactment of law; 2) legal certainty; 3) a prohibition of arbitrariness; 4) access to justice before independent and impartial courts, including a judicial review of administrative acts; 5) respect for human rights; 6) non-discrimination and equality before the law. ${ }^{19}$

The rule of law is mentioned as a principle of civil procedure in para. 3 Art. 2 of the CPC. Also, para. 1 Art. 10 of the CPC, entitled 'The rule of law and the law according to which the court decides cases', contains a provision that the court conducting the trial is guided by the principle of the rule of law. However, there is no further exposition on how the principle should be implemented in civil procedure, because other parts of this article are devoted only to the legislation according to which the court decides cases. Along with this, Art. 10 of

16 P Craig, 'Formal and Substantive Conceptions of the Rule of Law: An Analytical Framework' (1997) Public Law 467; B Tamanaha, On the Rule of Law. History, Politics, Theory (Cambridge University Press 2004) 91-113; RS Summers 'A Formal Theory of the Rule of Law” (1993) 27 Ratio Juris 127.

17 TRS Allan 'Constitutional justice: a liberal theory of the rule of law' (Publishing House 'Kyiv-Mohyla Academy' 2008) 35.

18 M Bennett 'The Rule of Law Means Literally What it Says: The Rule of Law' (2007) 32 Australian Journal of Legal Philosophy 90, 91.

19 European Commission for Democracy Through Law (Venice Commission), 'Report On The Rule Of Law' (Venice, 25-26 March 2011). < https://www.venice.coe.int/webforms/documents/default. aspx?pdffile=CDL-AD(2011)003rev-e > accessed 01 December 2020. 
the CPC states that the court decides cases in accordance with the Constitution of Ukraine, laws of Ukraine, international treaties, the binding nature of which was approved by the Verkhovna Rada of Ukraine (para. 2), and the court applies the case law of the ECtHR as a source of law (para. 4).

Since the CPC provisions on the rule of law are rather vague, the exact content of the principle shall be derived from the ECHR and from the case law of the ECtHR, in particular concerning the interpretation of para. 1 Art. 6 of the ECHR. These provisions are fundamental for the theory and practice of civil procedure, because despite the fact that the rule of law was fixed in the Preamble of the Universal Declaration of Human Rights, and in the Preamble and Art. 3 of the Statute of the Council of Europe, only the enshrinement of the rule of law in the Preamble of the ECHR and further interpretation of it in the case law of the ECtHR allowed to identify specific elements of the rule of law in a democratic society and enunciate a pan-European understanding of the rule of law. In its case law, the ECtHR has repeatedly emphasized that 'the rule of law, one of the fundamental principles of a democratic society, is inherent to all the articles of the ECHR' ${ }^{20}$ The ECtHR recognizes the following elements of the rule of law principle: a prohibition of arbitrariness, ${ }^{21}$ the lawfulness of human rights restrictions and requirements for the quality of the law, ${ }^{22}$ equality and non-discrimination, ${ }^{23}$ proportionality, ${ }^{24}$ legal certainty, which requires predictability in the application of legal norms,${ }^{25}$ non-retroactivity of laws, ${ }^{26}$ the principle of res judicata,${ }^{27}$ the uniformity of the case law, ${ }^{28}$ access to court,$^{29}$ the independence and impartiality of the court, ${ }^{30}$ a prohibition of the legislator's interference to the trial, ${ }^{31}$ and the execution of court decisions ${ }^{32}$ etc.

The conception of the rule of law applied by the ECtHR can be classified as a substantive one based on the priority of human rights. In this regard, the principle of legality, traditionally seen as an inherent principle of civil procedure, needs to be revisited. Legality should not be interpreted solely in the formal way (as a strict dogmatic observance of substantial and procedural legislation), but in addition it should include compliance with the quality requirements of the law. Thus, the case law of the ECtHR proves that all judgments rendered by national courts on the basis of existing law may, in their absolute majority, comply with the principle of legality, but this does not imply compliance with the rule of law. ${ }^{33}$ In this regard, any law has to be available to the person interested in it, and the latter shall be able to foresee the consequences of the law application. ${ }^{34}$ In other words, the law must meet

20 The Former King of Greece $v$ Greece App No 26701/94 (ECtHR, 23 November 2000) para 79; Amuur v France App No 19766/92 (ECtHR, 25 June 1996).

21 Malone $v$ United Kingdom App No 8691/79 (ECtHR, 02 September 1984) para 68.

22 The Sunday Times $v$ the United Kingdom App No 6538/74 (ECtHR, 26 April 1979); Kruslin v France App No 11801/85 (ECtHR, 24 April 1990).

23 'Relating to certain aspects of the laws on the use of languages in education in Belgium' $v$ Belgium (merits) App No 1474/62 (ECtHR, 23 July 1968); Thlimmenos v Geece App No 34369/97 (ECtHR, 06 April 2000).

24 Ocalan $v$ Turkey App No 46221/99 (ECtHR, 12 May 2005).

25 Kravchenko $v$ Ukraine App No 46673/06 (ECtHR, 30 June 2016) para 47.

26 Melnik v Ukraine App No 72286/01 (ECtHR, 28 March 2006).

27 Brumărescu $v$ Romania App No 28342/95 (ECtHR, 28 October 1999); Ryabykh $v$ Russia App No 52854/99 (ECtHR, 24 July 2003); Driza v Albania App No 33771/02 (ECtHR, 13 November 2007).

28 Nejdet Sahin and Perihan Sahin v Turkey App No 13279/05 (ECtHR, 20 October 2011) para 51, 58.

29 Golder v United Kingdom App No 4451/70 (ECtHR, 21 February 1975) para 34.

$30 \quad$ Pullar $v$ United Kingdom App No 22399/93 (ECtHR, 21 September 1994) para 65.

31 Stran Greek Refineries and Stratis Andreadis v Greece App No 13427/87 (ECtHR, 09 December 1994) para 49.

32 Immobiliare Saffi v Italy App No 22774/93 (ECtHR, 28 July 1999).

33 Kushoglu v Bulgaria App No 48191/99 (ECtHR, 03 July 2008).

34 Kruslin v France App No 11801/85 (ECtHR, 24 April 1990). 
such requirements as accessibility and foreseeability of the law, as well as its application in a manner not contrary to the rule of law and human rights.

Incorrect application of the ECHR or the case law of the ECtHR should serve as grounds for overturning or amending a lower court's judgment by a higher court. However, if there is a controversy between national law, on the one hand, and the ECHR or the case law of the $\mathrm{ECtHR}$, on the other, the latter shall prevail due to its international nature, which is decisive for the hierarchy of sources. The case law of the ECtHR can also be employed to strengthen the national court's reasoning even when national law is applied, as well as to fill the gaps that may exist at the level of national legislation.

Some difficulties may arise in national practice in cases where the parties refer to the case law of the ECtHR against other countries, or when the court has to apply such decisions on its own initiative, because there is no obligation to translate all judgments of the ECtHR into Ukrainian, except for judgments delivered against Ukraine. For example, Art. 6 of the Law of Ukraine 'On Enforcement of Judgments and Application of the Case Law of the European Court of Human Rights' provides that in order to implement general measures the state provides a translation and the publication of full texts of decisions in Ukrainian. According to this Law, in the absence of an official translation of the decisions of the ECtHR, the court must use the original text. In practice, the official translation is made for decisions of the ECtHR against Ukraine. The lack of access to case law for judges and the public in general in native languages makes it difficult for national courts to apply the full range of the case law of the ECtHR, in particular decisions against other states. However, the refusal of the national court to consider the arguments of the parties, in particular, when they are based on the case law of the ECtHR against other states may lead to a violation of para. 1 of Art. 6 of the ECHR. ${ }^{35}$

Another negative tendency is the misapplication of the case law of the ECtHR, in particular when some case is applied to facts to which it was not supposed to apply, or when the point of the ECtHR is treated incorrectly. Notable in this context is the Judgement of the Grand Chamber of the Supreme Court of 4 September 2019, in which the Supreme Court quotes, as the position of the ECtHR para. 70, of the decision in the case Ayder and Others v. Turkey, which fundamentally contains an interpretation of Turkish constitutional legislation, and not the position of the ECtHR in this case. So the Ukrainian Supreme Court referred to the clarification of Turkish national law, instead of the position of the ECtHR, on the dispute. ${ }^{36}$ The misapplication of the case law of the ECtHR reduces the efficacy of civil procedure and hinders the embodiment of the rule of law.

A characteristic feature of modern judicial practice is that the Supreme Court also interprets and applies the principle of the rule of law when evaluating the procedural actions of lower courts from the point of view of compliance with procedural norms. For example, in the Judgment of the Supreme Court of 12 September 2018 in case № 752/1016/17, considering the issue of the right to appeal the decisions of the court of first instance separately from the final judgment of the court on the merits of the case, the Civil Cassation Court noted that 'the provision of subpara. 8, para. 3, Art. 129 of the Constitution of Ukraine enshrines one of the main principles of judicial procedure ensuring the appeal of court decisions and judgments, except for special cases provided by law, and thus establishes guarantees of appellate review of court decisions.' The Civil Cassation Court emphasized that such provisions: 
should be applied with reference to Art. 8 of the Constitution of Ukraine proclaiming that the principle of the rule of law and the position of the ECtHR, according to which if the appellate courts exist in the national legal system, the state is obliged to ensure fundamental guarantees of para. 1 Art. 6 of the ECHR to participants of the appeal proceedings, taking into account the peculiarities of such proceedings and the procedural unity of the proceedings in the national legal order and the role of the appellate court in it. ${ }^{37}$

With reference to its previous case law, the Civil Cassation Court noted that in spite of the fact that para. 1 Art. 353 of the CPC enlists the interim decisions of the court of first instance that can be appealed separately from the judgment on the merits of the case, the issue of the admissibility of such an appeal in a particular case should be resolved taking into account whether some other remedies could possibly restore the rights of the person lodging the appeal. As a result, the Civil Cassation Court warns appellate courts from a 'formalistic approach to applying para. 1 Art. 353 of the CPC' and concludes that 'the court decision refusing the substitution of the creditor in the enforcement procedure and the renewal of the deadline for presenting the writ of execution can be subject to appeal, in spite of the fact that such a decision is not mentioned in para. 1 Art. 353 of CPC. ${ }^{\prime 38}$

In terms of the constitutional reform one can note the obvious trends in approaches to the application and the interpretation of the principles of civil procedural law. Firstly, the new CPC of Ukraine proclaims some general principles of law as principles of civil procedure, which indicates the predominance of a natural law approach to understanding the principles of civil procedure, in contrast to purely dogmatic and formalistic positivist jurisprudence. Secondly, national jurisprudence reveals tight interconnection between the rule of law and the guarantees of the right to a fair trial, as well as the potential impact of the case law of the ECtHR on the practice of national courts and its harmonization with international standards of civil procedure. Thirdly, as far as the theory of civil procedure is concerned, one can notice some positive developments since the principles of civil procedure, for a long time, have been dictated by a positivist approach. The catalogue of principles of civil procedure should now be revised, taking into account the impact of general principles of law in the area of civil justice, as well as their interpretation in the case law of the ECtHR, in particular, the application and interpretation of para. 1 Art. 6 of the ECHR, which establishes guarantees of fairness and the accessibility of justice.

\section{RIGHT TO A FAIR TRIAL:THE UKRAINIAN CONTEXT}

Of particular importance for the theory and practice of civil procedure is par. 1 of Art. 6 of the ECHR. This article is of paramount importance for the civil procedure of all the Member States of the ECHR, as it allows for the enunciation of basic international standards for a fair trial in civil cases. The right to a fair trial has repeatedly been the subject of close attention by many scholars. ${ }^{39}$ It is almost generally accepted in the literature to distinguish the structure of this right into two groups of guarantees: institutional (organizational) and procedural (functional). Institutional guarantees, established by law, of the right to a fair trial

37 Case No 752/1016/17 (Judgment of the Supreme Court, 12 September 2018) <http://reyestr.court.gov. ua/Review/77607397> accessed 01 December 2020. ibid.

39 P van Dijk, GJH van Hoof, Theory and Practice of the European Convention on Human Rights (Kluwer Law International 1998); D Vitkauskas, G Dikov, Protecting the Right to a Fair Trial under the European Convention on Human Rights: a Handbook for Legal Practitioners, $2^{\text {nd }}$ ed. (Council of Europe 2017); DJ Harris, M O’Boyle, Law of the European Convention on Human Rights, 3d ed. (Oxford University Press 2014). 
traditionally include access to a court, and its independence and impartiality. Procedural guarantees include public trial reasonable time of a trial, fair hearing, execution of court decisions etc. ${ }^{40}$

The above-mentioned guarantees of the right to a fair trial are generally reflected in civil procedural law. In accordance with Art. 2 of the CPC, the task of civil procedure is a fair, impartial trial and a resolution of civil cases within reasonable time aiming at effective protection of violated, unrecognized or disputed rights, freedoms or interests of individuals, rights and interests of legal entities or state interests.

Notwithstanding that the main guarantees of the right to a fair trial are enshrined in Ukrainian legislation, in the case law of the ECtHR against Ukraine, as well as in the practice of the Supreme Court, they reveal practical issues connected with the application of certain provisions of para. 1 Art. 6 of the ECHR. To be concise, we will focus on the one element of the right to a fair trial that the Supreme Court has often referred to in its recent practice, namely access to justice.

Access to justice problems often arise in Ukraine and are analysed by national courts in terms of the approaches developed by the ECtHR. The ECtHR notes that 'the right of access to the court is not absolute but may be subject to limitations; these are permitted by implication since the right of access by its very nature calls for regulation by the State, regulation which may vary in time and in place according to the needs and resources of the community and individuals. ${ }^{41}$ However, 'the limitations applied must not restrict or reduce the access left to the individual in such a way or to such an extent that the very essence of that right is impaired. Furthermore, a limitation will not be compatible with Article 6, para. 1 if it does not pursue a legitimate aim and if there is not a reasonable relationship of proportionality between the means employed and the aim sought to be achieved." ${ }^{2}$ These criteria for assessing the legitimacy of the restriction are called the test of proportionality in the practice of the ECtHR.

One illustrative example of the assessment of access to court in cases against Ukraine is the decision Nataliya Mikhaylenko v. Ukraine in which the ECtHR held illegal the provision of Ukrainian law depriving a legally incapable person of the right to raise before the court the issue of restoring legal capacity (para. 4 Art. 241 of the CPC) since there were no mandatory periodic review of whether the grounds for incapacitation still exist. In the ECtHR's view, the provision violated the applicant's right of access to a court, due to a disproportional limitation of the right, enshrined in para. 1 Art. 6 of the ECHR. ${ }^{43}$ As a result, the rules of national law were subsequently changed under the influence of the relevant practice of the ECtHR, and, according to current legislation, incapacitated persons can apply for a renewal of their legal capacity.

Later on in a different case, heard by the Supreme Court, a person, who had previously been declared incapable by a court decision and who lived in a special hospital, applied to the court for the reinstatement of her civil capacity and expressed readiness to undergo a forensic psychiatric examination, noting, in particular, that her passport was not at her disposal and she could not give a power of attorney to represent her interests. As a result, she asked to allow her attorney to participate in the case with a power of attorney being certified by the court decision. The District Court left her application without consideration with reference

40 See: C Grabenwarter 'Fundamental Judicial and Procedural Rights' in D Eglers (ed), European Fundamental Rights and Freedoms (Germany 2007) 162-164.

41 Ashingdane $v$ the United Kingdom App No 8225/78 (ECtHR, 28 May 1985).

42 Stanev v Bulgaria [GC] App No 36760/06 (ECtHR, 17 January 2012).

43 Nataliya Mikhaylenko v Ukraine App No 49069/11 (ECtHR, 30 May 2013). 
to the fact that her attorney may not be a proper representative of the incapable person. The Court of Appeal agreed, holding that the application for the renewal of civil capacity had been submitted on behalf of the applicant by a person who did not have the authority to conduct the case. The Supreme Court in this case concluded that lower courts had restricted the applicant's right of access to court, even despite the fact that she had the opportunity to apply to the court for the restoration of her civil capacity on her own motion. In particular, the Supreme Court stated that in the case Nataliya Mikhaylenko v. Ukraine, the ECtHR noted that the applicant's inability to directly seek the restoration of her legal capacity resulted in that matter not being examined by the courts. The absence of judicial review of that issue, which seriously affected many aspects of the applicant's life, could not be justified by the legitimate aims underpinning limitations on access to a court by incapacitated persons (para. 40). Therefore, the Supreme Court concluded that such a situation caused a denial of justice for the applicant so there had been a violation of para.1 Art. 6 of the ECHR. In view of the above, the cassation appeal was satisfied, the decisions of the courts of first and appellate instances were overturned, and the case was transferred to the court of first instance for new consideration. ${ }^{44}$

Another example of the ECtHR decision against Ukraine is the decision Tsezar and others $v$. Ukraine, which concerned the restriction of the right of access to court due to the fact that applicants were not able to bring any claims before the courts in the city of Donetsk whose territory is not controlled by the government of Ukraine. After the beginning of the 'anti-terrorist operation' legislation was amended, and the jurisdiction of courts situated in uncontrolled territories was transferred to other courts in territory controlled by Ukraine. After some time, all social benefits for people living in the Donetsk and Luhansk regions (not controlled by Ukraine) were ceased. The applicants in the present case complained of a violation of their right of access to a court under para. 1 Art. 6 of the ECHR, as they could not bring any claims against the decision of the Government to cease their social benefits, since the courts had been relocated from the territory of the armed conflict. Refusing to satisfy the application in this case, the ECtHR emphasized that the inability of the courts located in the city where the applicants reside to hear their cases was the result of an armed conflict in the region not controlled by the government. In view of the above, the issue is not that the respondent government deliberately restricted the exercise of the applicants' right of access to a court. First of all, the question arises as to whether the respondent state has used all available means to organize its judicial system in such a way as to make the rights guaranteed by Art. 6 of the ECHR effective in practice in the light of the established principle that the ECHR is designed to guarantee practical and effective rather than theoretical and illusory rights. Taking into account 'the objective obstacles that the Ukrainian authorities had to face, the ECtHR held that 'domestic authorities took the steps reasonably expected of them to ensure the proper functioning of the judicial system making it accessible to the residents of the territories currently outside the control of the Government'. Furthermore, 'in the absence of any evidence that the applicants' personal situation precluded them from making use of that system, the ECtHR concluded that in the circumstances of the present case the applicants' inability to bring their claims before the courts in their city of residence did not impair the very essence of their right of access to court. ${ }^{35}$ As we can see, in this case the ECtHR supported the actions of the national authorities restricting the right of access to national courts and found them proportionate.

44 Case No 756/552/17 (Judgment of the Supreme Court, 20 June 2018) <http://www.reyestr.court.gov.ua/ Review/74963689> accessed 01 December 2020. 


\section{PILOT JUDGMENTS OF THE ECtHR AND CIVIL PROCEDURE PRACTICE}

According to the Rule 61 of the Rules of Court, the ECtHR may adopt a pilot judgment where the facts of an application reveal, in the Contracting Party concerned, the existence of a structural or systemic problem or other similar dysfunction which has given rise or may give rise to similar applications. The ECtHR shall, in its pilot judgment, identify both the nature of the structural or systemic problem or other dysfunction as established as well as the type of remedial measures which the Contracting Party concerned is required to take at the domestic level by virtue of the operative provisions of the judgment.

There are several purposes of the pilot-judgment procedure. On the one hand, its aim is to indicate 'structural or systemic problem or other dysfunction' which exists at a national level and helps the state to take effective measures within a certain time limit in order to resolve the problem. On the other hand, an important aim of pilot judgment is to induce the respondent state to resolve large numbers of individual cases arising from the same structural problem, thus implementing the principle of subsidiarity which underpins the ECHR system, ${ }^{46}$ since the ECtHR can decide not to examine cases awaiting their resolution at a national level according to the pilot judgment.

In the case Yuriy Nikolaevich Ivanov v. Ukraine ${ }^{47}$ in 2009, the ECtHR recognized that the non-enforcement of court decisions, where the state is the debtor, is a systemic problem in the national legal order, however, this problem still remains unresolved.

Unfortunately, enforcement procedure should be recognized as the 'Achilles heel's8 of domestic civil procedure. According to statistics, the situation in the field of the enforcement of court decisions in Ukraine is disappointing, which has been repeatedly emphasized by both domestic researchers and the ECtHR. Thus, according to a survey conducted by the Razumkov Center in 2019, only $7.8 \%$ of Ukrainians surveyed believe that the situation with the execution of court decisions is satisfactory, while $54.3 \%$ hold the opposite view. ${ }^{49}$ -

In the context of the convention guarantees, the non-execution or the delayed execution of court decisions is a part of the wider problem of the violation of reasonable time for a trial requirement. According to the ECtHR's statistics for the entire period of its operation, of all violations found, $38.28 \%$ concerned para. 1 Art. 6 of the ECHR, in particular the fairness $(16.86 \%)$ and the reasonable time $(21.41 \%)$ of the trial. ${ }^{50}$ As of 2017 , at least 29,000 complaints concerned violations relating to reasonable time for the execution of court decisions. $^{51}$

The ECtHR has delivered several pilot judgments dealing with the non-execution of domestic court decisions against three states, namely, Ukraine (Yuriy Nikolaevich Ivanov v. Ukraine ${ }^{52}$ ), Moldova (Olaru and Others v. Moldova ${ }^{53}$ ) and Russia (Burdov v. Russia №2, ${ }^{54}$ Gerasimov and

$46 \quad$ Gerasimov and Others $v$ Russia App No 29920/05 (ECtHR, 01 July 2014) para 210.

47 Yuriy Nikolaevich Ivanov $v$ Ukraine (n 8) paras 84-88, 94.

48 Green Paper on improving the efficiency of the enforcement of judgments in the European Union: the attachment of bank accounts [2006] <https://eur-lex.europa.eu/legal-content/HR/ TXT/?uri=CELEX:52006DC0618> accessed 01 December 2020.

49 'Judiciary in the evaluation of citizens of Ukraine' (2019) 3-4 National security and defense 79.

50 European Court on Human Rights (n 7) p 6.

51 Burmych $v$ Ukraine (n 9) para 44.

52 Yuriy Nikolaevich Ivanov v Ukraine (n 8).

53 Olaru and Others $v$ Moldova App No 476/07 (ECtHR, 28 July 2009).

54 Burdov v Russia (No 2) App No 33509/04 (ECtHR, 15 January 2009). 
Others v. Russia ${ }^{55}$ ). These judgements concerned two repetitive problems in the national legal systems: firstly, undue delay in the enforcement of final court decisions where the debtor is the state or a public enterprise; secondly, an absence of an effective remedy for the protection of the right to a fair trial and the enforcement of court decisions within a reasonable time. As a result, in the judgments where the ECtHR found the violation of para. 1 Art. 6 and Art. 13 of the ECHR it obliged the states to provide an effective remedy to protect the right to a fair trial and the enforcement of domestic court decisions within a reasonable time at a national level and to secure sufficient redress for the non-enforcement of such decisions. Though circumstances of these cases were alike, the reaction of the abovementioned states to the judgments was different and the execution thereof at a national level was not successful in some cases, in the sense that remedies proposed were not recognized as being effective by the ECtHR.

The problem of the non-enforcement of court decisions in Ukraine was recognized as a systemic one by the ECtHR in its pilot judgment Yuriy Nikolaevich Ivanov v. Ukraine ${ }^{56}$ (hereinafter - Ivanov pilot judgment) in 2009. In this case the applicant retired from the Ukrainian Army and was entitled to a lump sum retirement payment and compensation for his uniform, but the payments were not made to him on his retirement which made him seek recovery of the debt in court. The court satisfied his claim in full, but the decision remained partially unenforced: at first, due to the lack of funds in the debtor's bank accounts and later, due to insufficient budgetary allocations for such payments and also the fact that the forced sale of assets belonging to military units was prohibited by the law. Despite this decision of the ECtHR and the long time that has elapsed since its adoption, Ukraine still does not have appropriate mechanisms in place to remedy the violation of the right to a fair trial within a reasonable time.

The ECtHR recognized that lengthy delays in the execution of the final national court's decisions were 'caused by a variety of dysfunctions in the national legal system' within the state's control, in particular, 'the lack of budgetary allocations', 'the bailiffs' omissions and the shortcomings in the national legislation', 'authorities' failure to take specific budgetary measures', and 'the introduction of bans on the attachment and sale of property belonging to state-owned or controlled companies. ${ }^{57}$ Given these circumstances, the ECtHR pointed out the complexity of the structural problem in this case, which 'prima facie requires the implementation of comprehensive and complex measures, possibly of a legislative and administrative character, involving various domestic authorities. ${ }^{58}$ In this decision the ECtHR gave Ukraine one year to establish an effective remedy or set of remedies capable of providing adequate and sufficient redress for the non-enforcement of the court's decision or delay in their enforcement in accordance with the principles established by the case law of the ECtHR. ${ }^{59}$

In response to the pilot judgment, Ukraine adopted the Law of Ukraine 'On State Guarantees of the Enforcement of Court Decisions ${ }^{\prime 60}$ of 05 June 2012 which set specific state guarantees in this respect. Under the Law plaintiff is entitled to compensation for the delay in the enforcement of court decision awarding payment or obliging the debtor to take certain actions relating to property as long as the debtor is a state body, state enterprise, institution, organization, or a legal entity, whose property cannot be sold in accordance with the law. Due to this law, the State Treasury of Ukraine is responsible for the enforcement of court decisions

55 Gerasimov and Others $v$ Russia App No 29920/05 (ECtHR, 01 July 2014) para 210.

56 ibid.

57 ibid, para 84

58 ibid, para 89.

59 ibid, paras $84-88,94$.

60 The Law of Ukraine 'On State Guarantees of the Enforcement of Court Decisions' No 4901-VI [2013] Vidomosti of the Verkhovna Rada 17/158 <https://zakon.rada.gov.ua/laws/show/4901-17\#Text> accessed 01 December 2020. 
delivered by national courts against state bodies and state enterprises. If the decision remains unenforced for a period exceeding three months, the state shall compensate three per cent of the outstanding debt per year. However, these guarantees are limited by the amount of funds allocated for the purpose according to the budget for each year.

However, the law seems not to be able to solve the problem because the state has taken responsibility for ensuring the enforcement of only a limited category of court decisions and the remedy provided is not a judicial one and therefore it does not allow all the relevant circumstances of each particular case to be taken into account. Attention should also be drawn to the amount of compensation. In its case law the ECtHR consistently notes that 'the level of compensation must not be unreasonable in comparison with the awards made by the ECtHR in similar cases, ${ }^{61}$ and this is one of the criteria by which the ECtHR reviews the effectiveness of compensatory remedies in cases concerned with excessive lengths of proceedings. The Law of Ukraine 'On State Guarantees of the Enforcement of Court Decisions', however, sets up a fixed amount of compensation which is unjustified and disproportionate in comparison with the compensation awarded by the ECtHR. In view of the above, the proposed compensation mechanism cannot be considered as an effective remedy for the protection of the right to execution of a court decision within a reasonable time under para. 1 Art. 6 and Art. 13 of the ECHR and the case law of the ECtHR.

Nevertheless, the state turned out to be unable to fulfil its obligations even under the law mentioned above which resulted in substantial debt. According to Art. 19 of the Law of Ukraine 'On the State Budget of 2019,62 the Cabinet of Ministers of Ukraine is entitled to restructure actual debts amounting to 7,544,562,370 UAH under court decisions, the execution of which is guaranteed by the state, and under the decisions of the ECtHR against Ukraine. The debts can be restructured through issuing financial treasury bills with up to a seven-year maturity, with one year of deferred payments and a $9.3 \%$ yield per annum. This mechanism was proposed as an alternative remedy for the protection of the right to the execution of court decisions within a reasonable time. However, according to the information of the Government of Ukraine, no interested persons have yet applied for the mentioned mechanism. ${ }^{63}$ Furthermore, the issue of enforcing judgments ordering performance of obligations in kind (rather than payment of a sum of money due), which has been highlighted in the case law of the ECtHR against other states, remains unresolved. ${ }^{64}$

The Committee of Ministers of the Council of Europe has repeatedly had to address the mentioned remedies, and as a result has worked out a set of measures to be taken by Ukraine in order to overcome the crisis under consideration. In particular, 'the three-step strategy' was proposed, including:

(1) the 'calculation of the amount of debt arising from unenforced decisions';

(2) the 'introduction of a payment scheme with certain conditions, or containing alternative solutions, to ensure the enforcement of still unenforced decisions';

(3) the introduction of the necessary adjustments to the state budget so that sufficient funds are made available for the effective functioning of the above-mentioned payment scheme, as well as necessary procedures to ensure that budgetary constraints are duly considered when

$61 \quad$ Burdov v Russia (No2) (n 51) para 99.

62 The Law of Ukraine 'On the State Budget of 2019' No 2629-VIII [2018] Vidomosti of the Verkhovna Rada 50/400 <https://zakon.rada.gov.ua/laws/show/2629-19\#Text> accessed 01 December 2020.

63 Burmych $v$ Ukraine (n 9) para 126.

64 Ilyushkin and Others $v$ Russia App No 5734/08 (ECtHR, 14 April 2012) paras 74-75; Gerasimov and Others $v$ Russia (n 52) para 210; Olaru and Others v Moldova (n 53). 
passing legislation to prevent situations of the non-enforcement of domestic court decisions rendered against the state or state enterprises.65

However, subsequent practice of the ECtHR against Ukraine evidences that this strategy was never put into life and for this reason the ECtHR had to renew the examination of applications in such cases due to a failure to provide effective domestic remedies. Estimates provided by the ECtHR reveal that a total of about 29,000 Ivanov-type applications have been submitted to the ECtHR since the first application in 1999. Since the beginning of 2016, the ECtHR has continued to receive a large number of such applications - over 200 per month. ${ }^{66}$

Crucial in this regard for both Ukraine and the practice of the ECtHR was the judgment in the case of Burmych and Others v. Ukraine of 12 October 2017 (hereinafter - Burmych) where the ECtHR took a fresh look at the problem of the non-enforcement of pilot judgments delivered against the states. The ECtHR revised its role in cases where the respondent state has not introduced the measures recommended by the ECtHR to solve the systemic problem. In this case, the ECtHR joined five applications in one proceeding with 12,143 Ivanov-type cases in which the applicants complained about a violation of para. 1 Art. of the ECHR regarding the non-enforcement of domestic court decisions against the state. In this judgment the ECtHR observes that 'it runs the risk of operating as part of the Ukrainian legal enforcement system and substituting itself for the Ukrainian authorities in directing appropriate and sufficient redress for the non-enforcement of domestic decisions, ${ }^{67}$ which is not compatible with the principle of subsidiarity and the aim of the pilot judgment procedure.

Pointing out the importance of distributing tasks between the ECtHR and the Committee of Ministers of the Council of Europe in the pilot judgment procedure, the ECtHR distinguishes between its own task - assistance to

the State in fulfilling its obligations under Art. 46 by seeking to indicate the type of measure that might be taken by the State in order to put an end to a systemic problem identified by the ECtHR, ${ }^{68}$ and the task of the Committee of Ministers - supervising the execution of judgments and ensuring 'that the State has discharged its legal obligation, including the taking of such general remedial measures as may be required by the pilot judgment in relation to affording relief to all the other victims, existing or potential, of the systemic defect found. ${ }^{69}$

In this respect the ECtHR notes that the question of the non-enforcement of domestic court decisions in Ukraine has been resolved by the ECtHR in the Ivanov pilot judgment, so the ECtHR has accomplished its task. The issue in the Burmych case relates to the non-enforcement of the Ivanov pilot judgment by Ukraine, therefore all the applications joined in the Burmych case 'should be dealt with in compliance with the obligation deriving from the pilot judgment' and transmitted to the Committee of Ministers 'in order for them to be dealt with in the framework of the general measures of execution of the above-mentioned Ivanov pilot judgment'. Moreover, the ECtHR held that it may strike any future Ivanov-type applications that may be lodged after the delivery of this judgment out of the list of its cases and transmit them directly to the Committee of Ministers, except for those applications which are found to be inadmissible under Art. 35 of the ECHR. ${ }^{70}$ The ECtHR employed such a drastic measure, for the first time, in the Burmych case when a number of criticisms were elicited from the ECtHR judges

\footnotetext{
$65 \quad$ Burmych $v$ Ukraine (n 9) para 128.

66 ibid, para 44.

67 ibid, para 155.

68 ibid, para 194.

69 ibid, para 194.

70 ibid, paras197-198, 221.
} 
themselves. Thus, in their joint dissenting opinion, the judges Yudkivska, Sajó, Bianku, Karakaş, De Gaetano, Laffranque and Motoc argue that:

the present judgment has nothing to do with the legal interpretation of human rights. It concerns a matter of judicial policy only, and as such completely changes the wellestablished paradigm of the ECHR system [...]. The ECtHR cannot, on account of a heavy caseload, just cease to perform its judicial tasks, leave the applicants in an unpredictable position and transfer the judicial responsibility on to a political body which unfortunately has so far had little impact on helping the respondent Government to properly execute the pilot judgment and to enact general measures. ${ }^{71}$

Among other arguments the following are given. Firstly, the judges insist on the fact that the circumstances of those joined 12,134 applications have not been examined so their similarity cannot be established with certainty. Secondly, this judgment, in fact, denies the right of future applicants to access to the ECtHR and justifies the ECtHR's reluctance to consider the cases by reference to its previous position regarding the functions of the pilot judgment procedure. In such a context, the ECtHR 'appears to become a filtering body for the Committee of Ministers $^{72}$ regarding future Ivanov-type applications that can be struck out of the list of cases and transmitted to the Committee of Ministers. 'It would mean transferring the determination of human rights claims from a judicial authority, as the Convention system requires, to a political body, albeit a collective one. ${ }^{73}$ However, it is contrary to the Protocol № 11 which 'explicitly abolished any competence on the part of the Committee of Ministers to decide on violations of the ECHR, and retained only the Committee's competence as to the execution of the judgments of the ECtHR' ${ }^{74}$ Thirdly, bureaucratic reasons for 'reducing the burden on the ECtHR' underlie the judgment under consideration and leave the applicants in a state of legal uncertainty as instead of obtaining the ECtHR judgment in their cases they, in fact, 'will have to wait sine die for a political monitoring mechanism of the domestic reforms. ${ }^{75}$

In our opinion, arguments can be found both for and against such a judgment of the ECtHR, and it can hardly be unambiguously assessed, but it is obvious in this context that the ECtHR, as has been emphasized by the Burmych case, indicates that all states which ratified the ECHR must abide by their obligations and ultimately fulfil the requirements of the ECtHR's pilot judgments, particularly with regard to the introduction of effective remedies for the right to a fair trial and the enforcement of judgments within a reasonable time, as well as for the elimination of the drawbacks existing in the national system that guarantee the right to a fair trial. Otherwise, states put themselves at risk of having an infinite series of payments of fair satisfaction with an endless series of applications.

This raises the question of the root causes leading to the non-enforcement of domestic court decisions in Ukraine and the need for further action to be taken at the national level to meet the requirements of the Ivanov pilot judgment and improve the situation in this area. In response to the ECtHR requirements, the Budgetary Programme № КПКВ 350-404017 ('Programme 4040 ') on guaranteeing the enforcement of the national courts' decisions was introduced, which is aimed at the systematization and further liquidation of debts in this category of cases. With the support of the Office of the Council of Europe, a study entitled 'The root causes to the nonenforcement of domestic judicial decisions in Ukraine' was conducted with our participation. ${ }^{76}$

71 ibid, Joint Dissenting Opinion of Judges Yudkivska, Sajó, Bianku, Karakaş, De Gaetano, Laffranque and Motoc, para 1.

72 ibid, para 6.

73 ibid, para 13.

74 ibid, para 15.

75 ibid, para 14.

76 M Musiyaka, A Zayets, T Tsuvina, V Sushchenko, 'The root causes to the non-enforcement of domestic judicial decisions in Ukraine' 3-4 National security and defense 2. 
In order to identify the root causes leading to the non-enforcement and late enforcement of court decisions where the debtor is the state and to make recommendations for their elimination, 305,554 court decisions (the total number of decisions in 'Program 4040' as of February 2019) were divided into several categories: a) decisions in social security cases, b) decisions in labour disputes, c) decisions against legal entities for which the state is responsible. We personally studied the largest category, namely the decisions in social security cases (the total number in the 'Programme 4040' was 27,600 cases, and one per cent of this total number - 2,760 cases - was selected for the analysis).

The analysis allowed identification of the following root causes leading to the non-enforcement of court decisions in this category of cases: a) a lack of sufficient budget funding; b) defects in writs due to the established court practice, according to which the courts in such cases do not determine the exact amount of money to be collected and instead just order the relevant public authority to recalculate the allowance; c) inconsistent legislation on providing social benefits to broad groups of citizens in the absence of proper financial justification: first, laws are passed to increase social guarantees for certain groups of citizens, and then the state tries to limit such payments due to lack of budget funding by passing new laws, which afterwards are declared unconstitutional, ${ }^{77}$ leading to lawsuits for the recovery of unreceived payments; d) the complexity of the legal regulation of this area. ${ }^{78}$ Among other reasons for the total noncompliance with the guarantees of the execution of court decisions, in which the debtor is the state, members of the working group identified: shortcomings of organizational and legal regulation of enforcement procedure, the violation of legislation governing an enforcement procedure by bailiffs, various moratoriums for enforcement against certain types of companies, the lack of a culture of respecting court decisions and their enforcement, the lack of an effective legal system of interaction between bodies on which the enforcement of court decisions depends, excessive formalism in the regulation of the enforcement procedure, the lack of effective mechanisms to prevent abuse in the enforcement procedure, etc. ${ }^{79}$

The need to overcome these problems calls for changes in the regulation of the enforcement procedure. The first steps to improve it were taken as a part of constitutional reform. According to Art. $129^{1}$ of the Constitution of Ukraine, a court decision is recognized as binding. The state ensures the execution of a court decision in the manner prescribed by law. The court controls the execution of the court decision. These constitutional provisions are specified at the level of civil procedure legislation. According to Art. 18 of the CPC, court decisions that have entered into force are binding for all public authorities, enterprises, institutions, organizations, officials and citizens and should be enforced in Ukraine and abroad in cases established by the international treaties of Ukraine. Failure to execute a court decision is the basis for liability established by law. Finally, simultaneously with the adoption

77 See: Judgment of the Constitutional Court of Ukraine in case on the Constitutional Petition of 46 Deputies of Ukraine on the Compliance of the Provisions of Art 29, 36, Part 2 of Art 56, Part 2 of Art 62, Part 1 of Art 66, items 7, 9, 12, 13, 14, 23, 29, 30, 39, 41, 43, 44, 45, 46 of Art 71, Art 98, 101, 103, 111 of the Law of Ukraine 'On the State Budget of Ukraine on 2007' with the Constitution of Ukraine (constitutionality) (case about social guaranties of the citizens) of 09 July 2007, no 6-рп/2007 $<$ https://zakon.rada.gov.ua/laws/show/v0a6p710-07> accessed 01 December 2020; Judgment of the Constitutional Court of Ukraine in case on the Constitutional Petitions of the Supreme Court of Ukraine on the Compliance of the Certain Provisions of Art 65 of Sec I, paras 61, 62, 63, 66 of Sec II, para 3 of Sec III of the Law of Ukraine 'On the State Budget of Ukraine on 2008 and Amendments to Certain Legislative Acts of Ukraine' and on the Constitutional Petition of 101 Deputies of Ukraine on the Compliance of the Provisions of Art 67 of Sec I, items 1-4, 6-22, 24-100 of Sec II of the Law of Ukraine 'On the State Budget of Ukraine on 2008 and on Amendments to Certain Legislative Acts of Ukraine' with the Constitution of Ukraine (constitutionality) (case about the subject and content of the Law 'On the State Budget of Ukraine') of 22 May 2008, No 10-pп/2008 <https://zakon.rada.gov.ua/laws/ show/v010p710-08> accessed 01 December 2020. 
of the amendments to the Constitution of Ukraine, two laws that directly relate to this area were adopted: the Law of Ukraine 'On bodies and persons carrying out enforcement of court decisions and decisions of other bodies' ${ }^{80}$ and the Law of Ukraine 'On Enforcement Procedure. ${ }^{81}$ These laws enshrined new organizational and procedural principles governing the enforcement procedure. In this context, the transition to a mixed system of the enforcement of court decisions with the introduction of private bailiffs, the digitalization of enforcement proceedings, a simplified procedure for recovering debts in certain cases, etc., aimed at accelerating enforcement proceedings and increasing efficiency, requires special attention. ${ }^{82}$ It may seem that a continuous improvement of legislation aimed at bringing national rules of procedural law in line with international standards of fair trial should significantly increase the efficiency of enforcement procedure, but so far it does not completely solve the problem of the non-enforcement of court decisions in Ukraine. The systemic problem of ensuring the enforcement of court decisions where the debtor is the state and state-owned enterprises remains unsolved, even after having been repeatedly addressed by the ECtHR in its judgments against Ukraine. Therefore, at present, the priority task, in this respect, is to introduce complex effective remedies at the national level for the enforcement of court decisions within a reasonable time, which would combine both preventive and compensatory elements according to para. 1, Art. 6 and Art. 13 of the ECHR.

\section{THE REVIEW OF A CASE ON EXCEPTIONAL CIRCUMSTANCES AFTER THE JUDGEMENT OF THE ECTHR}

The convention system provides for the possibility of interplay between national courts and the ECtHR, which may take the form of a review of a domestic court's decision on exceptional circumstances at a national level after an international judicial institution, whose jurisdiction is recognized by Ukraine, having found a violation of international obligations by Ukraine (subpara. 2, para. 3, Art. 423 of the CPC).

The legal cause for a review of the decision on exceptional circumstances after the ECtHR recognized Ukraine's breach of its obligations is contained in Art. 10 of the Law of Ukraine 'On Enforcement of Decisions and Application of the Case Law of the European Court of Human Rights', according to which a retrial by a court is recognized as one of the additional, individual measures, along with compensation, that can restore a previous legal status the applicant had before the violation of the ECHR (restitutio in integrum). However, this type of review has a subsidiary nature since it is not necessary for all the cases where the ECtHR found a violation.

This is confirmed by the Recommendation № R (2000) 2 of the Committee of Ministers to member states on the re-examination or the reopening of certain cases at a domestic level following judgments of the ECtHR according to which:

Contracting Parties, in particular, have to examine their national legal systems with a view to ensuring that there exist adequate possibilities of re-examination of the case, including reopening of proceedings, in instances where the Court has found a

\footnotetext{
80 The Law of Ukraine 'On bodies and persons carrying out enforcement of court decisions and decisions of other bodies' No 1403-VIII [2016] Vidomosti of the Verkhovna Rada 29/535 <https://zakon.rada. gov.ua/laws/show/1403-19\#Text> accessed 01 December 2020.

81 The Law of Ukraine 'On Enforcement Procedure' No 1404-VIII [2016] Vidomosti of the Verkhovna Rada 30/542 <https://zakon.rada.gov.ua/laws/show/1404-19\#Text> accessed 01 December 2020.

82 See: V Turkanova, 'Open Enforcement: New Approach of Ukraine in Access to Justice' (2020) 1 Access to justice in Eastern Europe 58.
} 
violation of the Convention, especially where: (i) the injured party continues to suffer very serious negative consequences because of the outcome of the domestic decision at issue, which are not adequately remedied by the just satisfaction and cannot be rectified except by re-examination or reopening, and (ii) the judgment of the Court leads to the conclusion that (a) the impugned domestic decision is on the merits contrary to the Convention, or (b) the violation found is based on procedural errors or shortcomings of such gravity that a serious doubt is cast on the outcome of the domestic proceedings complained of. ${ }^{83}$

In Bochan v. Ukraine (№ 2) the ECtHR analysed the effectiveness of this type of review in the previous wording of the CPC. ${ }^{84}$ In this case, the applicant received a decision of the ECtHR in case Bochan v. Ukraine, ${ }^{85}$ in which the ECtHR found the violation of para. 1 Art. 6 of the ECHR with regard to the right to an independent and impartial court and the principle of legal certainty because the Supreme Court of Ukraine unjustifiably changed the territorial jurisdiction of the applicant's case. After this judgment, the applicant contested the proceedings on the grounds of so called 'exceptional circumstances' in the Supreme Court of Ukraine. The applicant was refused a review of her case because the grounds on which the ECtHR had found a violation of para. 1 Art. 6 of the ECHR in Bochan v. Ukraine do not indicate the need to review the case at the level of national law. Such a situation encouraged the applicant to file a new application to the ECtHR. In its judgment Bochan v. Ukraine (No 2), the ECtHR noted that the Supreme Court of Ukraine, conducting the trial in the applicant's case, had 'grossly misrepresented' the findings contained in the ECtHR judgment, in particular, 'the Supreme Court recounted that the ECtHR had found that the domestic courts' decisions in the applicant's case had been lawful and well founded and that she had been awarded just satisfaction for the violation of the "reasonable time" guarantee. But these allegations are clearly incorrect and do not correspond to the content of the ECtHR decision, so the ECtHR considers the Supreme Court's interpretation of the decision to constitute 'gross arbitrariness' and 'denial of justice', which led to 'the effect of defeating the applicant's attempt to have her property claim examined in the light of the Court's judgment in her previous case in the framework of the cassation-type procedure provided for under domestic law'. Consequently, the ECtHR found a violation of para. 1 Art. 6 of the ECHR in this case. ${ }^{86}$

Currently such a type of review is conducted by the Grand Chamber of the Supreme Court. In 2019, according to the statistics of the Supreme Court, $88 \%$ of applications for a review on exceptional circumstances were due to the ECtHR finding a violation of the ECHR by Ukraine. These include 11 applications lodged in administrative proceedings, 3 applications in commercial proceedings, 15 applications in civil proceedings, 46 applications in criminal proceedings, 3 applications in cases of administrative offenses. In 2019 only one application in civil case was considered on merit and sustained, while in a significant number of cases the applications were returned, or the case was quashed. ${ }^{87}$

Interpreting subpara. 2, para. 3 Art. 423 of the CPC, the Supreme Court in one of its judgements pointed out that the review of judgments in exceptional circumstances as an individual measure to enforce the ECtHR decision cannot be used in cases where violations

83 Recommendation No R (2000) 2 of the Committee of Ministers to member states on the re-examination or reopening of certain cases at domestic level following judgments of the European Court of Human Rights [2000] <https://search.coe.int/cm/Pages/result_details.aspx?ObjectID=09000016805e2f06> accessed 01 December 2020.

84 Bochan v Ukraine (No 2) (n 83).

85 Bochan $v$ Ukraine App No 7577/02 (ECtHR, 03 May 2007).

86 Bochan v Ukraine (No 2) (n 83).

87 Analysis of the Administering of Justice by the Grand Chamber of the Supreme Court in 2019 [2020] 14-15 <https://supreme.court.gov.ua/userfiles/media/Analiz_zdijsn_VPVS_2019.pdf> accessed 01 December 2020. 
of international law obligations: 1) must be eliminated only by taking measures of a general nature; 2) have nothing to do with a person who has filed an application for a review of court decisions; 3 ) have nothing to do with the case under review of the court decision in which the application was filed; 4) concern only the duration of the trial or the duration of the enforcement procedure. ${ }^{88}$

Thus, it can be concluded that in a large number of cases it is the award of fair satisfaction by the ECtHR that ensures the restoration of the violated rights, and, therefore, a new trial at the national level is unnecessary. For example, after the ECtHR recognizes a violation of a reasonable time for the trial or the publicity of the trial, the resumption of proceedings at the national level is not required. At the same time, the case law of the ECtHR against Ukraine and subsequent decisions of the Supreme Court show that in case of violations of such guarantees as the right to a fair trial as equality of arms ${ }^{89}$ the independence and the impartiality of a court, ${ }^{90}$ access to court, ${ }^{91}$ or such substantive rights as the right for private and family life (Art. 8 of the ECHR) (2) $^{92}$ or the right to peaceful enjoyment of possessions (Art. 1 of the First Protocol of the ECHR) ${ }^{93}$ the review on exceptional circumstances may be necessary to provide the restitutio in integrum. For example, in the case of Lazarenko $v$. Ukraine, the ECtHR found a violation of the equality of arms due to the failure to notify the applicant about appellate proceedings in his case and, as a result, his inability to file his objections. ${ }^{94}$ In this case, after the review of the judgment due to exceptional circumstances, the Supreme Court remanded the case to the appellate court for further trial. ${ }^{95}$

\section{CONCLUSIONS}

The study of the impact of the ECHR and the case law of the ECtHR on civil procedure in Ukraine leads to the conclusion that the harmonization of Ukrainian civil procedure legislation with fair trial standards has become a defining trend of constitutional reform in the area of justice and civil procedure reform in 2017 in Ukraine. This can be seen not only at the level of the modernization of the provisions of the CPC, but also at the level of judicial practice, especially the practice of the new Supreme Court. At the same time, the changes in the civil procedure legislation had objective reasons and, despite different views and discussions on the expected consequences of judicial reform, became a response to the existing challenges aiming at improving the efficiency of civil procedure. These changes were inspired by the influence of the ECHR and the case law of the ECtHR, as well as the conclusions and recommendations of the Council of Europe, and generally reflected European trends in civil procedure.

The direct impact of the ECHR and the case law of the ECtHR on the field of civil justice manifests itself in the updated catalogue of civil justice principles and new trends in approaches to the interpretation of the principles of civil procedural law. The inclusion of

88 Case No 2-428/11 (Judgment of the Grand Chamber of the Supreme Court, 28 March 2018) <http:// reyestr.court.gov.ua/Review/73304966> accessed 01 December 2020.

89 Lazarenko v Ukraine App No 70329/12 (ECtHR, 27 June 2017).

90 Denisov v Ukraine App No 76639/11 (ECtHR, 25 September 2018).

91 Shestopalova $v$ Ukraine App No 55339/07 (ECtHR, 21 December 2017).

92 Lazoriva $v$ Ukraine App No 6878/14 (ECtHR, 17 April 2018).

93 Batkivska Turbota Foundation v Ukraine App No 5876/15 (ECtHR, 09 October 2018).

94 Lazarenko $v$ Ukraine (n 88).

95 Case No 2a-2573/11 (Judgment of the Grand Chamber of the Supreme Court, 07 February 2018) <http://reyestr.court.gov.ua/Review/72243661> accessed 01 December 2020. 
the general principles of law (in particular the rule of law principle) into the list of civil procedure principles is indicative of a natural law approach overcoming purely dogmatic positivist jurisprudence in the domain of civil procedure.

There is a tight interconnection between the rule of law and the guarantees of the right to a fair trial. That is why the catalogue of principles of civil justice calls for revision considering the impact of general principles of law on civil justice, as well as a need for their interpretation in terms of the case law of the ECtHR, in particular, with regard to the application and the interpretation of para. 1 Art. 6 of the ECHR, which establishes guarantees of fairness and the accessibility of justice.

Of key importance, in terms of compliance of civil procedure with international standards, is the implementation of the guarantees of the right to a fair trial, enshrined in para. 1 Art. 6 of the ECHR at national level. Despite the enshrinement of certain elements of this right in civil procedure legislation of Ukraine, its implementation remains impeded due to problems with access to the practice of the ECtHR for judges and participants of a trial, which results in a misapplication of the case law of ECtHR by national courts.

As a result of the reform, the Supreme Court's jurisprudence was propelled to a new level where the court's main task is to ensure the unity of national case law. The practice of the Supreme Court has reached a brand-new level of quality in terms of implementing the requirements of the rule of law and the right to a fair trial, having abandoned a purely dogmatic interpretation of law and an excessive formalism which used to be inherent to Ukrainian judicial practice for a long time.

The influence of the ECHR and the case law of the ECtHR on the sphere of civil procedure is also manifested through the adoption of a pilot judgment of the ECtHR against Ukraine. In order to enforce the decisions Yuriy Nikolaevich Ivanov v. Ukraine and Burmych v. Ukraine, preventive and compensatory remedies vindicating the right to a trial and the enforcement of court decisions within a reasonable time should be implemented according to para. 1 , Art. 6 and Art. 13 of the ECHR.

Of crucial importance for the implementation of human rights obligations is the reexamination of the case by national courts after the ECtHR has found a violation whenever it is necessary to restore the applicant's rights at the domestic level. This is done through the review of court decisions on exceptional circumstances (subpara. 2, para. 3, Art. 423 of the $\mathrm{CPC}$ ) which in general meets the requirements for this type of review, though there were some negative cases (Bochan v. Ukraine № 2).

\section{REFERENCES}

Allan TRS, 'Constitutional justice: a liberal theory of the rule of law' (Kyiv: Publishing House 'KyivMohyla Academy', 2008).

Bennett M, 'The Rule of Law Means Literally What it Says: The Rule of Law' (2007) 32 Australian Journal of Legal Philosophy 90.

Craig P, 'Formal and Substantive Conceptions of the Rule of Law: An Analytical Framework' (1997) Public Law 467

De Salvia M, Precedents of the European Court of Human Rights. Guidelines for case law relating to the European Convention for the Protection of Human Rights and Fundamental Freedoms. Judicial practice from 1960 to 2002 (Yuridicheskiy tsentr Press 2004).

Dijk P, GJH Vvan Hoof GJH, Theory and Practice of the European Convention on Human Rights (Kluwer Law International, 1998). 
Grabenwarter C,'Fundamental Judicial and Procedural Rights' in European Fundamental Rights and Freedoms. Eglers D. (edit) (Germany, 2007) 151-164.

Harris DJ, O'Boyle M, Law of the European Convention on Human Rights, 3d ed. (Oxford University Press, 2014).

Turkanova V, 'Open Enforcement: New Approach of Ukraine in Access to Justice' (2020) 1 Access to justice in Eastern Europe 58.

Musiyaka M, Zayets A, Tsuvina T, Sushchenko V et al, 'The root causes to the non-enforcement of domestic judicial decisions in Ukraine'. 3-4 National security and defense 2.

Summers RS, 'A Formal Theory of the Rule of Law" (1993) 27 Ratio Juris 127.

Tamanaha B, On the Rule of Law. History, Politics, Theory (Cambridge University Press, 2004).

Vitkauskas D, Dikov G, Protecting the Right to a Fair Trial under the European Convention on Human Rights: a Handbook for Legal Practicioners, $2^{\text {nd }}$ ed. (Council of Europe, 2017). 